\title{
Community forestry and its implications for Northern Ontario
}

\author{
by P.N. Duinker ${ }^{1}$, P.W. Matakala ${ }^{2}$ and D. Zhang ${ }^{3}$
}

\begin{abstract}
Community forestry is becoming an increasingly important policy issue for provincial governments in Canada. Many singleindustry communities in the northern parts of the provinces, surrounded as they are by forests, are looking to forest resources for possible economic diversification and stability. At the same time as there is increasing interest, there is little understanding about what community forestry could and should be for communities surrounded by Crown land forests. This paper looks at some definitions and dimensions of community forestry, as well as reviewing briefly some experiences with it. We examine various ways in which community forestry might be different from provincial government forestry and industrial forestry, and reflect on whether community forestry could lead to improvements in forest management. We conclude with some thoughts on potential future directions for community forestry in Ontario.
\end{abstract}

Key words: community forestry, Crown land forests, singleindustry communities, land tenure, local involvement, economic stability, Northern Ontario

\section{Introduction}

Community forestry is becoming a much-discussed form of forest land tenure and management in Canada at present. This attention comes at a time when many communities in forested areas, especially single-industry towns dependent on mining, forests or tourism, are searching for ways to diversify their economies. In doing so, they aim to become more resilient to the vagaries of external economic forces; indeed, the aim for some is to survive at all.

Community forestry has many definitions. The USDA Forest Service (undated) defined community forestry as lands owned and operated for forestry or allied purposes by the community (village, city, town, school, district, township, or other political sub-division) for the benefit of that community. With reference to developing countries, Gregersen and Lundgren (1990) suggested that community forestry is synonymous with social forestry, referring to "a broad range of tree- or forest-related activities undertaken by rural landowners and community groups to provide products for their own use and for generating local income'". The following propositions have emerged in our discussions with colleagues: (a) community forestry is community development based on multiple resources in forested ecosystems; (b) community forestry exists when the community is driving landuse decisions; and (c) community forestry exists when a

\footnotetext{
1.2 Associate professor and graduate student, respectively, School of Forestry, Lakehead University, Thunder Bay, Ontario P7B 5E1.

${ }^{3}$ Graduate student, Faculty of Forestry, University of British Columbia, Vancouver, BC V6T 1W5.

Paper presented at a session of the CIF Forest Management Working Group, Annual Meeting of the Canadian Institute of Forestry, Fredericton, August 1990.
}

\section{Résumé}

Les gouvernements provinciaux du Canadas' intéressent de plus en plus à la foresterie communautaire. De nombreuses collectivités à vocation unique vivent entourées de forêts dans les régions septentrionales des provinces et se tournent maintenant vers les ressources forestières pour diversifier leur économie et atteindre une certaine stabilité. En même temps qu'augmente l'intérêt pour cette question, on comprend encore mal ce que pourrait ou devrait représenter la foresterie communautaire pour ces collectivités situées au milieu des terres forestières de la Couronne. Le présent article examine quelques définitions et certains aspects de la foresterie communautaire et se penche brièvement sur quelques expériences dans ce domaine. On y examine également en quoi la foresterie communautaire differe de la foresterie publique provinciale et de la foresterie industrielle, et dans quelle mesure la foresterie communautaire peut contribuer à améliorer la gestion forestière. On conclue par quelques réflexions sur les orientations possibles de la foresterie communautaire en Ontario.

Mots clés: foresterie communautaire, forêts de la Couronne, collectivités à vocation unique, tenure participation régionale, stabilité économique, Nord de l'Ontario

community is satisfied with its involvement in and benefits from management of the surrounding forest land.

Our current conception of community forestry in Northern Ontario is: "management of forested lands directly or indirectly by representatives of local communities". Representation of local communities could be achieved in a variety of ways, a key one of which would be local government. Community forestry is not private forestry, as in private woodlots; it is not industrial forestry, as in private enterprise with freehold land or timber leases from provincial governments; and it is not provincial government forestry, as in Crownland management by Ontario Ministry of Natural Resources.

\section{Experience with Community Forestry}

There is a wide range of experience, from failures to successes and everything between, with community forestry in developing countries (e.g., RAPA, 1989). For North America, Dunster (1989) gave a lengthy appendix of examples of forestry ventures that have some features associated with comunity forestry, but few of these measure up to our definition above. When we discuss community forestry with colleagues, we are frequently offered examples of what are suggested to be community forests, or strong surrogates, including so-called agreement forests in Southern Ontario, where community-owned forests are managed by OMNR, as well as a variety of mechanisms and agreements that get local people involved in affairs of forest management. These examples also usually fall short of our view of what community forestry is, although in many cases they may go a long way to providing specific communities with the levels of control and benefits they want.

Two illustrative examples of community forestry in Canada involve municipally-run forest estates in British Columbia 
the North Cowichan Municipal Forest, and the Mission Tree Farm Licence. We present synopses of each of these examples.

\section{North Cowichan Municipal Forest}

The Municipality of North Cowichan, near the town of Duncan north of Victoria, owns some 5,000 ha of forested land that was first clearcut in the decades prior to the 1940s, and then cut in various passes using a diameter-limit approach up to the 1970s. To improve the municipal revenues from the forest, to provide some local employment, and to begin a process of revitalizing the degraded forest, the Municipal Council put a new management strategy in place and hired a professional forest manager. Some millions of dollars of provincial and federal government monies were obtained for silvicultural work to improve future timber availability. The timber operations are self-sustaining, in that revenues from logging cover the costs of operations and administration. Surplus revenues are saved for future years when timber costs might exceed revenues from log sales, or when special expenditures need to be made. The forest is managed primarily for timber, with increasing accommodation and special programs for recreational and educational uses.

\section{The Mission Tree Farm Licence}

The Municipality of Mission has held a provincial tree farm licence since the late $1950 \mathrm{~s}$. This licence of roughly 9,000 ha is for the most part no different than any other tree farm licence in British Columbia, except that the others are much bigger and are held by forest-products companies. The Mission forest is also managed primarily for timber with special programs for recreational and educational use, and operates under the same self-sufficiency principle as does North Cowichan. A full-time forester is employed by the Municipality to manage the forest.

\section{Some Dimensions of Community Forestry in Northern Ontario}

\section{Spatial Scale}

Woodlot forestry in Ontario takes place at a spatial extent of tens to hundreds of hectares. Industrial and provincial forestry, on the other hand, occurs generally at a spatial scale of hundred-thousands to millions of hectares. We feel that community forestry in Northern Ontario is probably most meaningfully considered for forests in the range of tenthousands of hectares. The North Cowichan Municipal Forest is about 5,000 ha, the Mission Tree Farm Licence is about 9,000, and the Geraldton Community Forest Proposal (Rogers, 1990) envelops roughly 70,000 ha. If we assume that community forestry in Northern Ontario must have an element of successful timber business associated with it, then it seems reasonable to think in terms of thousands or tenthousands of hectares, especially with slow-growing boreal forest in mind. However, the infrastructure required to manage forest estates of hundred-thousands of hectares or larger would likely be out of the range of capability of most communities in Northern Ontario.

\section{Range of Forest Values Covered by Management}

Many people seem to believe that community forestry inherently means multiple-use forest management. This is often said to be desirable also in the management of any forest land, from small private woodlots to large industrially or provincially managed forests. We are reluctant to narrow our conception of community forestry only to cases where multiple-use management is strongly in force. Multiple-use forest management is probably appropriate for most proposed community forests. However, both the North Cowichan and Mission community forests are managed primarily for timber purposes. Flows of other benefits (except community awareness and education about forests and forestry) are not explicitly pursued, but are accepted as they may result from the timber management. Therefore, successful community forestry in Northern Ontario may not need to be tied strongly to multiple-use management. There will be cases where strong multiple-use management is desirable, and also successful cases where strongly timber-oriented management is appropriate.

On a related matter, it is difficult to imagine successful community forestry in Northern Ontario without successful commercial enterprise of some sort. Such enterprises will usually involve timber harvest and sale, but they could also include trapping, tourism, commercial fish harvest, and others. Our expectation is that most of the forest-management bills would be paid for by sales of timber of one kind or another.

\section{Degree of Involvement and Control by Community People}

We believe that public consultation by industrial and provincial forest managers about forest-management decisions, even through improved consultation mechanisms, does not and will not satisfy many Northern Ontario community people about the degree to which they feel they have adequate input to and control over forest-resource management. Our sense is that community folk in Northern Ontario who say they want community forestry, want it because it permits them to have what they feel is an adequate level of authority over management of the surrounding environment and resources, for benefit flows that accrue first and foremost to the local community.

We recognize some risks both in increasing the role of public sentiment in forest-management decision-making and in shifting the control over management from the provincial level to the local level. Regarding public involvement, the threat to forest management is that, because public whims may change as rapidly as the weather, forest management that tries to follow public desires may be technically impossible to implement. However, the forest sector in Canada is increasingly recognizing that forest management decisionmaking can no longer be dominated by provincial governments, the forest-products industry, and forestry professionals. It must be characterized by a healthy balance of public and professional involvement. On the matter of localization of control, one might say that the imbalance has been in favour of regional and provincial interests, with the interests of local communities lying mainly in the hands of senior levels of governance and private enterprise. Perhaps full localization of control of forests on provincial Crown land would constitute an imbalance as well. For example, some communities might be tempted to accelerate forest exploitation in hard times to maintain high levels of economic activity; long-term resource stewardship may thus be compromised without a broader (i.e., provincial) interest to balance local interests. 
The forest sector should aim, therefore, for prompt and widespread establishment of agreeable partnerships between local and regional interests, and between public and professional input. Community forestry is a promising approach to achieving these balances. Compared to current provincial and industrial forestry in Canada, community forestry means a much stronger degree of forest-management authority and decision control in the hands of people in the local community on behalf of the local populace. Community forestry should go beyond even the best of local public consultation mechanisms in provincial and industrial forestry. It should also go beyond simply having municipal government control a forest. It should combine a balance of local and provincial control of a forest with strong and meaningful consultation programs.

\section{Would Community Forestry Improve Forest Management in Northern Ontario?}

We have heard many times the question of whether community forestry can do things for communities and forests that industrial and provincial forestry can not. We feel there are several ways in which community forestry could be an improvement over the current implementations of industrial and provincial forestry in Northern Ontario. This of course is not to say that industrial and provincial forestry could not be improved; indeed they could, and in many respects are now and will further following a ruling from the Environmental Assessment Board regarding the Class Environmental Assessment for Timber Management on Crown Lands in Ontario. We will indicate below where we feel provincial and industrial forestry could be modified to meet goals that community forestry is intended or expected to meet.

1. Community forestry is expected to involve smaller-scale, more environmentally benign forest-management practices.

We have learned that clearcuts in the North Cowichan and Mission forests are notably smaller than clearcuts in neighbouring industrial forests. While there is little solid empirical evidence to show that the environmental impacts from small clearcuts are demonstrably less and fewer than those from larger clearcuts, most people, trained and untrained, intuitively feel that smaller is better from an environmental point of view. Theoretically, industrial forestry could operate in smaller blocks as well, but economies of scale are thus lost, and resistance to such changes would be significant.

To the degree that community forestry means more "gentle" forest-management technology akin to that used in many private woodlots in Canada, community forestry could be seen to be less environmentally damaging than industrial and provincial forestry based on larger-scale, "harsher" technology. However, industrial and provincial forestry has been characterized recently by numerous improvements on behalf of the environment. Examples include high-flotation tires on skidders and harvesters, safer chemical herbicides, and switches from chemical to biological insecticides. By several measures, industrial and provincial forestry is becoming much less environmentally harmful. We are not convinced that community forestry in Northern Ontario of necessity means more-environmentally-friendly forestry. Perhaps if local people are in charge of managing their own forest environment, their design of forestmanagement interventions would be more sensitive to environmental considerations than the design of interventions in industrial and provincial forestry. On the other hand, if community forestry is expected to involve more-intensive forest management (discussed below), the higher intensity of ecosystem manipulation perhaps could be seen as undesirable from an environmental point of view.

2. Community forestry seems to be seen as conducive to more-intensive forest-management practices.

Despite plenty of advocacy for increasing the intensity of forest management on industrially and provincially managed forests in Northern Ontario, there is really only modest movement in this direction compared to the technical potentials of intensive forest management. Scarification, planting and control of competing vegetation are implemented on many cutovers, but precommercial and commercial thinning are virtually absent in operational terms. We get a sense from people who talk about community forestry that intensive forest management would be part and parcel of community forestry. Interestingly, it is highly unlikely that the large programs of intensive management intervention (mainly thinning, fertilizing and pruning) in juvenile and young stands in the North Cowichan forest in the 1980s would have taken place, especially at such an accelerated schedule, if monies external to the forest operations had not been garnered. Therefore, intensive management is only likely in community forestry if external funds are available, or if forest revenues permit it, and the latter is far from sure.

In the establishment of community forests on provincial Crown land in Northern Ontario, it is not unreasonable that significant provincial funding be made available for intensive forest management by the community forest managers. For one thing, in arrangements where the land remains in the ownership of the province (the most likely scenario, we believe), such provincial funding would fall in line with current contractual arrangements with forest-products companies through forest-management agreements. For another, the provincial government has in some cases permitted significant resource degradation to occur on provincial lands surrounding rural northern communities (e.g., forest highgrading, inadequate regeneration). Should a community forest become established on such lands, the burden of forest rehabilitation would lean legitimately on provincial shoulders.

3. A much stronger connection is likely in community forestry between forest revenues and forest costs.

In provincial forestry, costs of delivering the forestmanagement program can be calculated, and revenues from forest management and forestry activity reckoned, but there is no direct allocation back to forest management of all monies generated directly or indirectly from the managed forests. In industrial forestry in Northern Ontario, woodlands operations are generally run as cost centres, so the objective is always to deliver wood to the mill at reasonable or least possible cost. In such cases, there are no revenues derived from a woodlands operation, except where timber is sold rather than delivered to the company's mills. In community forestry, there should be a direct connection between forest-management revenues and forest-management expenses. This is indeed the case with North Cowichan and 
Mission, and also with the Algonquin Forestry Authority, a locally-based corporation managing the exploitable forests of Algonquin Provincial Park.

A direct link between forest revenues and forest costs can be seen as both advantageous and disadvantageous. On one hand, if prices for raw forest products such as timber are relatively high, this provides an opportunity to prevent forestenterprise profits from being siphoned away from potential forest-related investment. On the other hand, if prices are low, or in some cases "normal", it may be that timber extraction is the only management intervention that can be afforded given forest revenues. Regardless, community forestry in Northern Ontario probably has a much higher chance of being characterized by such a direct link than the chances of changing industrial or provincial forestry along these lines.

4. A higher degree of meaningful public involvement in resources decision-making, and thus public satisfaction, is attainable with community forestry.

As evident in the Class Environmental Assessment, most parties in the forestry community are agreeing that more and better public consultation is required in industrial and provincial forest management in Northern Ontario. These are positive developments, but come nowhere close to the model of community forestry where the local community itself has control and responsibility for forest-land management. We believe it would be difficult to come close in industrial or provincial forestry without at the same time adopting some form of community forestry.

\section{Community forestry lends itself more to increased aware-} ness and interest of the public in forest management.

It is quite possible that community citizens could become more aware of and interested in forest management with a change in the authority over the land surrounding the community from industrial or provincial management to community management. However, we feel this depends entirely on the emphasis put on these factors by both community forestry people and industrial/provincial forestry people. In the case of North Cowichan, increasing public awareness of forests and forest management is a very important and explicit goal of the municipal forestry program. However, townspeople in Mission are relatively unaware about forest management despite the fact that the municipality has been managing a large forest for more than three decades. On the other hand, people in the Miramichi region of New Brunswick are becoming much more familiar with forest management through industrial efforts to take town folk to the woods to see for themselves what forestry is all about ( $\mathrm{O}^{\prime} \mathrm{Neill}$, 1990).

We conclude here that awareness of and interest in forestry by community people will only occur where forest managers mount strong programs with these objectives in mind. Such programs are equally as possible in industrial and provincial forestry as they are in community forestry. One factor that favours such programs in community forestry is the likelihood that the community forest is close to the community, whereas much industrial and provincial forestry takes place long distances from towns or villages, and few but the woodsworkers, hunters and fishermen ever visit the sites of remote operations.
6. Community forestry provides greater opportunity to maintain stability of local economic activity.

Due again to economies of scale and consolidated operations, industrial and provincial forestry often is characterized by a decade or two of intensive activity in forests near one community, and then several decades of nothing while operations continue near other communities. Community forestry is seen as a mechanism for preventing this "shifting forestry", such that there would be relatively constant levels of forestry activity from year to year in perpetuity in the forests surrounding a community. Most communities would surely favour this kind of stability.

Another feature of local economic activity is the possibility for community forestry people to arrange for local contractors for woodswork, transportation, and in some cases sorting of wood before it is shipped to buyers. If entrepreneurs knew that a community forest would support constant (even if relatively low) levels of work from year to year, they might be more willing to set up contracting services and businesses in small communities rather than operating out of larger urban centres from which they can more easily follow the path of industrial or provincial forestmanagement activity concentrations.

\section{Discussion and Conclusions}

Our basic question has been: in what ways is community forestry different, or could it be different, than industrial and provincial government forestry, and can these be considered as shifts towards improved forest stewardship? In theory, community forestry could be a great improvement in forest management over industrial and provincial forestry. However, in theory, industrial and provincial forestry could also be improved a great deal along many of the same lines as the improvements that might come from implementing community forestry. Unfortunately, there is insufficient experience with community forestry in Canada, at least as we have defined it, for a proper comparison with the ubiquitous industrial and provincial forestry that has characterized this country's development. We believe that a very promising way to give forest-based communities a reasonable degree of control over their own biophysical environments and socio-economic destinies is to implement some form of community forestry. Not all communities will be willing and able to accept this kind of responsibility, but for those that are, the opportunities for local control and strong local consultation should be explored.

In Canada, there is sufficiently little experience with community-scale management of rather large forest estates that policy development and real experiments are needed. This would fall in line with "adaptive muddling", a promising framework for averting the tragedy of the commons (De Young and Kaplan, 1988). In adaptive muddling, three basic principles are applied. One principle calls for strong overall policy to provide the unambiguous direction and broad-scale stability under which innovative and adaptive resource management can occur. Another calls for extensive local experimentation with resource-management strategies and approaches to increase the range of experience upon which to draw as humanity moves into an uncertain and precarious future. We can not know what approaches might work better than our current ones until we try them, 
so carefully crafted local deviations from the norm in resource management are needed. One element of the strong overall resource-management administration and policy must be to support the local experimentation, and help the local experimenters survive if their experimental venture fails. The third principle calls for strong local leadership, where each willing member of a community is called upon to take a leadership role in community projects according to the special talents that the person may bring to the initiatives.

Ontario (and indeed, the rest of Canada) needs to muddle adaptively to discover the real promise of community forestry for the future of the province's forest resources. Strong, stability-generating policy is needed that recognizes our profound ignorance about community forestry and that gives it a fair chance to prove itself. The forest-products industry has a role here in providing technical support, and perhaps most importantly in providing markets for timber from community forests.

As for communities in forested areas, especially communities whose economic futures are uncertain and even in jeopardy, they need to be patient, and to understand that a few judiciously chosen experiments may need to be operated for some five or ten years before it would be fair to expect the provincial government, if the experiments are successful, to move toward broader implementation of community forestry. Community forestry must under no circumstances be seen as a panacea for the economic woes of every community surrounded by Crown forest. Community forestry will be difficult, with pitfalls at every turn. Managers of community forests will still have many difficult decisions to make regarding conflicts among resource users. Major constraints against successful establishment of community forests will arise, a few of which are: (a) the need to account for current land and forest tenures and commitments; (b) the resistance of some members of the forestry fraternity to new ways of implementing forest management in Canada; and (c) the reluctance of many communities, and indeed some proportion of the population in all communities, to take on the work and responsibility involved in community forestry programs.

Community forestry in Ontario shows great promise. If the attitude of forest-sector people is one of receptiveness to new ideas, adventure, experimentation, partnership, and entrepreneurship, the community-forestry developments of the next decade, even if not as successful as hoped, will be very exciting and worthwhile.

\section{References}

De Young, R. and S. Kaplan. 1988. On averting the tragedy of the commons. Environmental Management 12: 273-283.

Dunster, J.A. 1989. Establishing the Geraldton Community Forest. Phase I: Concepts and Background Information. Report to the Town of Geraldton, Geraldton, Ontario.

Gregersen, H.M. and A.L. Lundgren. 1990. Forestry for Sustainable Development: Concepts and a Framework for Action. Working Paper 1, Forestry for Sustainable Development Program, College of Natural Resources, University of Minnesota, St. Paul, Minnesota.

O'Neill, H.J. 1990. Removing public fears. In: Preprint Book, 71st Annual Meeting, Woodlands Section, Canadian Pulp and Paper Association, pp. E63-E67. Canadian Pulp and Paper Association, Montreal, Quebec.

RAPA. 1989. Community Forestry: Lessons from Case Studies in Asia and the Pacific. Food and Agriculture Organization of the United Nations, Bangkok, Thailand. 248 pp.

Rogers, M. 1990. The Geraldton Sustainable Development Initiative (Planning for the 21st Century). Paper presented at the Annual General Meeting of the Ontario Professional Foresters' Association, February 1990, Sault Ste. Marie, Ontario.

USDA Forest Service. Undated. Community Forests: Their development in Europe and Their Possibilities in the United States. Report B-19. USDA Forest Service, Washington, D.C. $28 \mathrm{pp}$. 